\title{
チョク建築の平面設計概念 \\ ネパールの王宮における中庭建築の研究 その 3 \\ GRID OF FLOOR PLANNING FOR CHOK \\ Quadrangle Architecture of the Royal Buildings of Nepal Part 3
}

\author{
黒津高行* \\ Takayuki KUROTSU
}

\begin{abstract}
This paper is the Part Three of the Research in Chok (Quadrangle) Architecture of the Royal Buildings of Nepal. In this paper, a grid floor planning of Chok was examined, on examples $M \bar{u} l$ Chok and Sundara Chok of Patan Darbār, which are typical patterns of Chok Architecture, on the basis of the findings of a photo-survey and an actual measurement.

As a results, we were able to draw out the following conclusion :

Chok Architectures were constructed as an aggregate under a consistent site planning. For a Patan Darbār, there was a site planning based on the standard grid for $M \bar{u} l$ Chok and Sundara Chok. And the grid length of the pole was 7.5 Hät since the late 14th century, as the standard units.

In the floor planning, $M \bar{u} l$ Chok was designed according to the $8 \times 8$ square standard grid, in coincidence with the standard grid of the entire site planning, thus following a form from Bhadgaon Darbār. As for Sundara Chok, foundations of Quadrangle were designed according to the standard grid of the entire site planning, but buildings surrounding it were built by the different $6 \times 6$ square standard grid. It is estimated that the differences between the two kinds of Chok came from the different functions these buildings performed. The grid floor planning that adopts different standard units for buildings with different uses is also found in architectures in ancient India. It is considered that architectural design of each Chok of Royal Buildings in Nepal also followed traditional techniques by taking into consideration the historical background.
\end{abstract}

Keywords : floor planning, Patan Darbār, Mūl Chok, Sundara Chok, grid, Hāt 平面計画，パタン王宮，ムール・チョク，スンダラ・チョク，基準格子，ハート

序

本稿は，ネパールの王宮におけるチョク建築（中庭建 築）を建築史の観点から分析し，その成立過程を明らか にすることを目的とした研究の, 第 3 稿である。第 1 稿"! ではチョク建築の構造について, 第 2 稿 ${ }^{2}$ ではチョク建 築の機能について検討した。その結果，(1)チョク建築の 典型は, マッラ王朝のムール・チョクとスンダラ・チョ クにみられ, シャ八王朝になると増拡され, 発展した形 式の建築が出現すること，(2)チョク建築の機能からみた 歴史的展開の特質は, 宗教機能のチョクと, 居住機能の チョクが並立する点, および，時代が降ると次第に，機 能分化し,新たにチョクが加えられてゆく点にあること, (3)王宮建築は, ムール・チョク,スンダラ・チョクなど, チョク建築を主要な構成要素とする複合体として, 17 世紀半ばの 3 王国分立時代後のマッラ王朝には王宮建築
としての完成した形式が成立し，その後，18 世紀後半 のシャ八王朝初期に変容し, 現在の形式に至ったとみる ことができること，を明らかにした。

この稿においては, 写真測量および実測調查の結果を 基に, チョク建築の典型的な形式を持つパタン王宮の ムール・チョクとスンダラ・チョクを例に, 設計概念に ついて平面を中心に論じる。

\section{1. パタン王宮ムール・チョクの基準格子 \\ パタン王宮ムール・チョク Mūl Chok は, ほぼ正方} 形中庭の四方に総 2 階建の建物を廻す形式である。中庭 四方に建つ各棟の外壁はれんが積みであり，ムール・ チョクの平面規模は,このれんが壁で囲まれた範囲とな るから, その計画の基準線はれんが壁の配置と係わって いると考えられる。そこで，れんが壁厚を基準值と仮定 


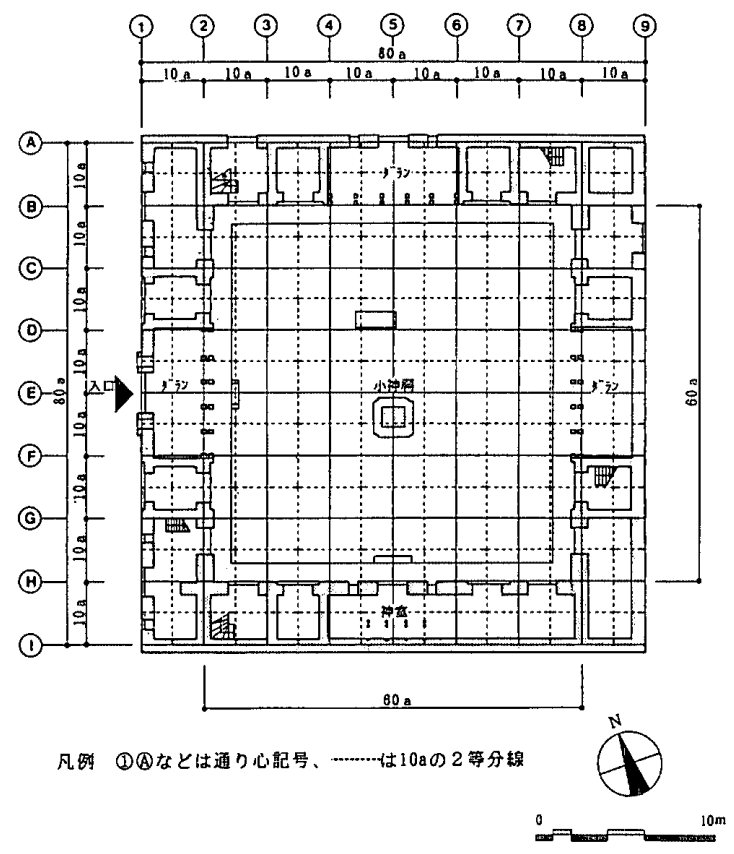

图一1 パタン王宮ムール・チョク平面の基準格子

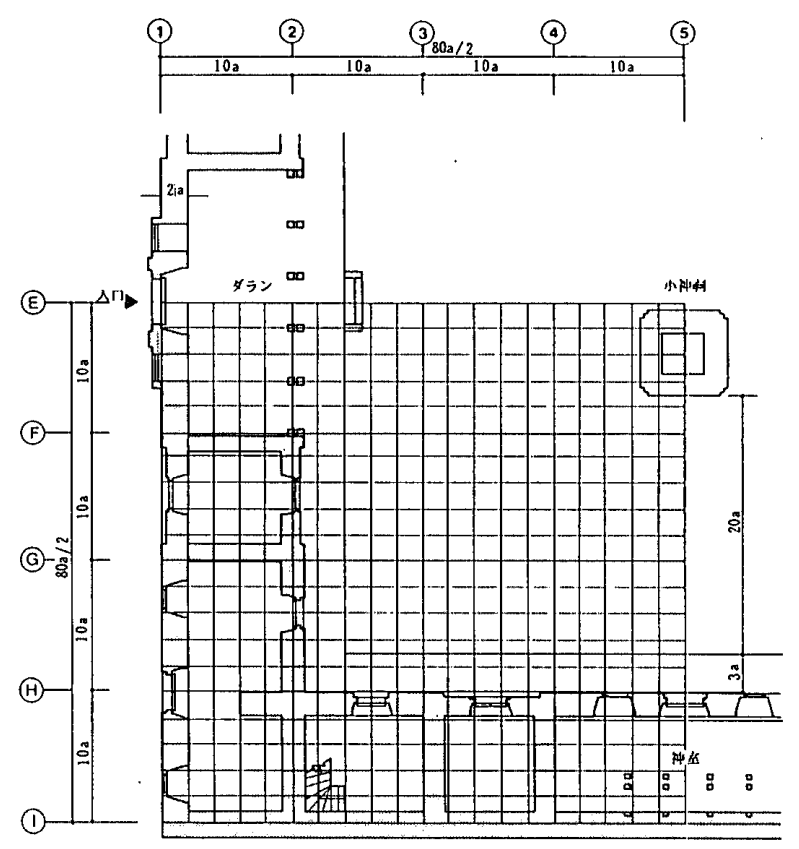

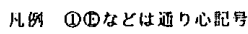

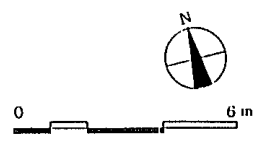

図一2 パタン王宮ムール・チョク平面の基準格子(部分詳細図)

基線格子上で一致する（図一2）。

この事実を南西隅の扉の例でみると, 中庭南面の扉は, 内周壁の壁心(2)通りから東側に $6 a$ の基線上に, 屝の中 心を据えている。また, 中庭東面の屝も同様に, 内周壁 面円通りから北側に $6 a$ の基線上に，屝の中心線を据え ている。すなわち, 中庭の入隅部の扉は, 基準格子 $10 a$ の 2 等分線から $1 a$ 分内側に心ずれして位置する。これ は，扉と壁面長さの比例関係上，入隅部の壁面を長くす ることにより，中庭立面の視覚上のバランスを配慮した 計画と推測される。

したがって, 通り心の一方は壁面, 直角方向の他方は 壁心であっても4)，扉位置は，それを基準とした補助基 準格子が同様に適用できるから，この基準格子は平面の 通り心設定の概念として妥当なものと理解できる。

いっぱう, 中庭に建つ小神秱は, 中庭南面の基壇の儆 石先端から小神祠の基壇の葛石先端まで $20 a$ の位置に あり, 中庭の南北軸線上に据えられる。その配置寸法は, 平面の基準寸法 $10 a$ の 2 倍を採っている。小神闹の配 置上の基点は，基壇の葛石先端にあると考えられる。末 た, その平面は, 基壇が $10 a$ の 3 分の 2 , 而部分が $10 a$ の 3 分の 1 を一辺とする正方形である。高さは活ぼ $10 a$ である(図一 3 )。断面は, 一辺 $10 a$ の正方形老計画の 基準寸法としている。すなわち，この小神祠の配置およ び柌本体も，平面の基準格子にみられる $10 a$ 基準寸 法として用いている。

小神訪司の位置が，ムール・チョク平面全体を秩序づけ る $10 a$ の基準格子と直接対応しないのは, 建物完成後 


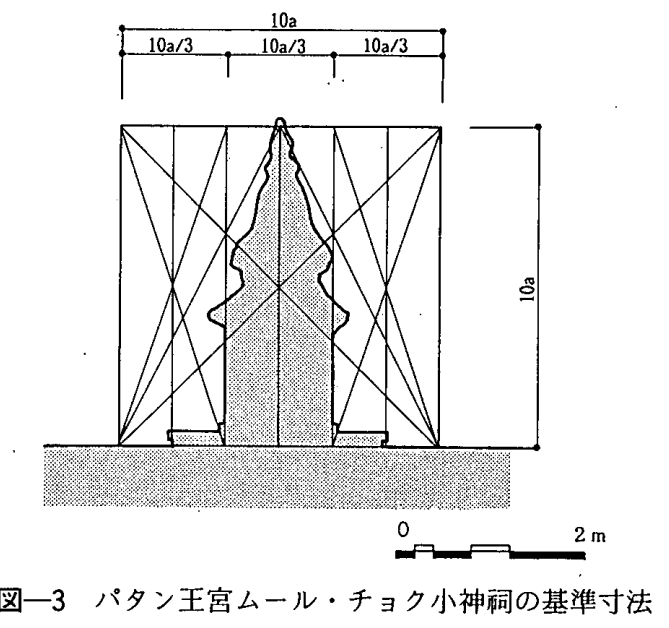

に改めて位置を決めたからであろう。この小神祠は，王 の守護神タレジュを崇めて設けられたものであるから， ムール・チョク南棟の神室造営後に寄進されたと考えら れる。中庭に小神祠を建てる形式は，バドガウン王宮と カトマンズ王宮では見られないから，17 世紀半ばのパ タン王宮独自のものと推測される。

したがって，小神嗣は，本来のムール・チョクの形式 にないものであるから，その位置は平面の基準格子と直 接一致しなくともよい。

なお，小神祠の位置は，基準格子 $10 a$ を $6 a: 4 a$ に 分ける補助基準寸法とも対応している（図一2）。この小

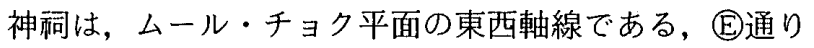
から南側に $4 a$ の基線上に，その中心を据えている。こ れは，当初の設計手法に順じた配置であり，平面寸法の 基準格子が生きている。

以上のように，ムール・チョクの平面計画は，10a の値を基準寸法とする正方形基準格子に基づいている。 さらに, 外周壁の壁厚 $2 a$ の補助基準格子を用いて, 平 面細部までが計画されている。

\section{2. パタン王宮スンダラ・チョクの基準格子}

パタン王宮スンダラ・チョク Sundara Chok は，中庭 を囲む形式のバルコニー付総 3 階建の建築であり, 平面 規模は外周壁の位置で計画していると考えられる。そこ で，スンダラ・チョク西棟正面の壁厚 $630 \mathrm{~mm}$ を $2 b$ と 仮定して，実測図に基づく平面全体に適用してみる。

スンダラ・チョクの平面は, 一辺 $60 b$ の正方形とし て捉えられ, 平面全体に対応する $s=10 b$ の正方形基 準格子が設定できる(図一4)。すなわち,スンダラ・チョ クの平面は， $6 s \times 6 s$ の正方形基準格子で計画してい ると考えられる。

この格子の基準線と 1 階の壁・柱位置の対芯関係を南 北方向の通り心でみると, (1)(114通りは外周壁壁心, (II) (11)通りは内周壁中庭側面, (10)(通りは室の間仕切壁面, 東西方向の通り心では, (a)通りは外周壁壁心, @(f)通

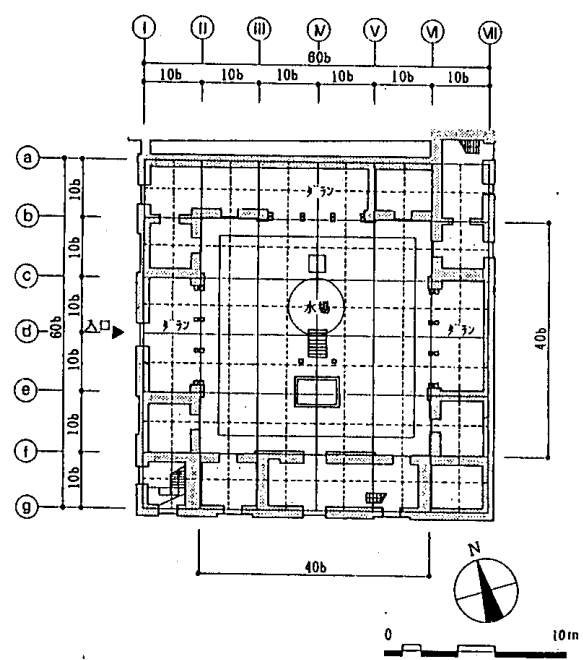

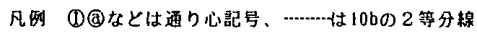

図一4 パタン王宮スンダラ・チョク平面の基準格子

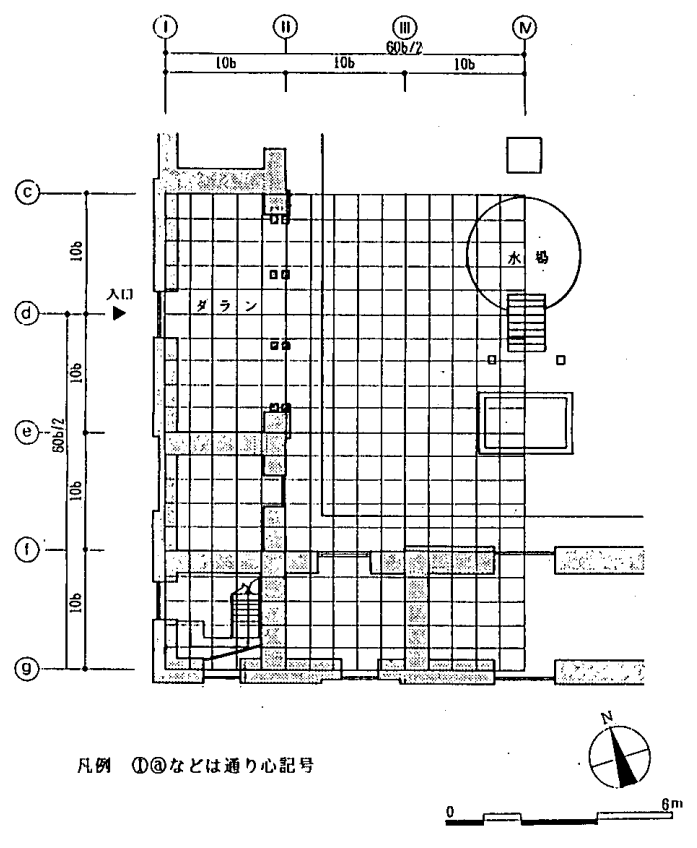

図一5 パタン王宮スンダラ・チョク平面の基準格子 (部分詳細図)

りは内周壁中庭側面，〔通りはダランの間仕切壁面， にそれぞれ一致する。⑩と@通りは平面の中心線であ る。すなわち, スンダラ・チョクの平面は, 一辺 $40 b$ の正方形中庭の四方に幅 $10 b$ (中庭を囲む四周の建物 の梁行）の建物を廻した形である。さらに，中庭の平面 一辺 $40 b$ を $20 b$ づつ 2 等分してダランの間口（桁行） とし，その中央部分にダランを配する形で計画している。 また，空・扉などの開口部の位置については，10 b の正方形基準格子を 2 等分する位置または基準線上に, 開口部の中心を概放据えている。これは，1・2階とも ほぼ同様である。

さらに，3階の中庭側のバルコニーの方立て位置は， 中庭側壁面長さ $40 b$ を 20 等分した割り付けとなってい る。方立ての割り付け寸法は $2 b$ である。この寸法は, 
バルコニーの内法幅でもある。すなわち，方立て位置は， 基準格子 $10 b$ を 5 等分した $2 b$ の基線と一致する。

この補助基準寸法 $2 b$ を，1 階平面に設定すると，ダ ランの柱列位置はこの基線と一致する（図一5）。これを 西棟ダランでみると, 柱列両端の柱心は, スンダラ・チョ ク平面の東西軸線@通りから，南と北にそれぞれ $8 b$ の 位置の基線と合う。北・東棟ダランについても同様であ る。それぞれの柱列間口は, 補助基準寸法 $2 b$ の 8 倍す なわち $16 b$ となっている。

したがって，スンダラ・チョクの平面計画は, $10 b$ の値を基準寸法とする正方形基準格子に基づいている。 さらに, 外周壁の壁厚 $2 b$ の補助基準格子を用いて, 平 面細部までが計画されている。平面に正方形基準格子が 設定でき，その基準寸法が外周壁の壁厚に基づいている 点は,ムール・チョクと同様である。

\section{3. 基準寸法の歴史的背景}

パタン王宮のムール・チョクとスンダラ・チョクの平 面には，それぞれの建物の壁厚に基づく基準值を用いた 基準格子が，設計の基本となっていることを指摘した。 この節では，これらの基準寸法の測定単位の由来につい て明らかにし，これらの単位がそれぞれのチョクに採用 された歴史的背景を考察する。

\section{1）マッラ王朝時代の間竿とハート尺}

ネパールの歴史上の長さの主要な単位に, ハートHat がある5)。ハートは肘から中指までの長さとされ゙), 古 代インドの尺度”之同様に、身体寸法に基づく寸法体系 の中に位置付けられる。この単位をメートル法に換算す ると, 1 ハート $=457.2 \mathrm{~mm}$ となる ${ }^{8)}$ 。

このハート尺は，5－6 世紀に成立したインドの建築 書『マーナサーラ』に記される小腕尺キシュク・ハスタ9) に相当する寸法と推測され，古代インド以来の単位と考 えられる。マッラ王族は，5世紀半ばにネパールに王朝 を確立していたリッチャヴィ王族と同様に，インド圈か らカトマンズ盆地に入ったインド・アーリア語族に属す るクシャトリアであるから年，インドの文化もこの頃に ネパールにもたらされたと推測できる。したがって,ハー ト尺はネパールにおいても伝統的な測定単位であったと 考えられ，ネパールにおける王宮のチョク建築の寸法体 系に，ハート尺が用いられている可能性が高い。

実際，このハート尺を基にした間竿の存在が史料から 知られる。年代記によると, ジャヤスティティ・マッラ 王 Jayasthiti Malla（在位 1382-1395）は, 竹の間竿の 長さを 10.5 ハートから 7.5 ハートに変更している11。 ムール・チョクが創立されたのは, 14 世紀のバドガウ ン王宮である。15世紀半ばには, ヤクシャ・マッラ王 Yakṣa Malla (1428-1479) がバドガウン王宮を造営し ている。この時の造営に用いられた間竿の長さは, 後述
のように, 7.5 ハートであったと推測される。

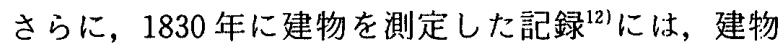
寸法をハートで記している。すなわち，この頃には，舆 さの測定単位としてハートを確かに用いていることがわ かる。

\section{2）パタン王宮におけるニつの基準寸法}

ムール・チョク ムール・チョクの基準寸法の場 合， $k=10 a$ の值は図一6に示すように, 記録にみら机 る 7.5 ハートと一致しており，ムール・チョクが伝統的 な基準寸法によって設計されたことが明らかとなる。

パタン王宮ムール・チョクの平面は正方形として捉え られ，外周壁の通り心は，南側・北側では壁心，東側・ 西側では壁外面で計画している。この正方形の--辺 $80 a$ は, 実測寸法でみると, 南北 $27,468 \mathrm{~mm}(28,155 \mathrm{~mm}-$ 壁厚 $687 \mathrm{~mm}$ ) ・東西 $27,500 \mathrm{~mm}$ である。これ妾八ート 尺に換算すると,南北 60 ハート・東西 60 ハートとなる。 この場合の実測寸法に対するハート尺换算值の誤差は $0.13 \%$ と $0.25 \%$ であるから，ムール・チョクの平面 は, 一辺 60 ハート (以下 $H$ と略す) の正方形上みて上

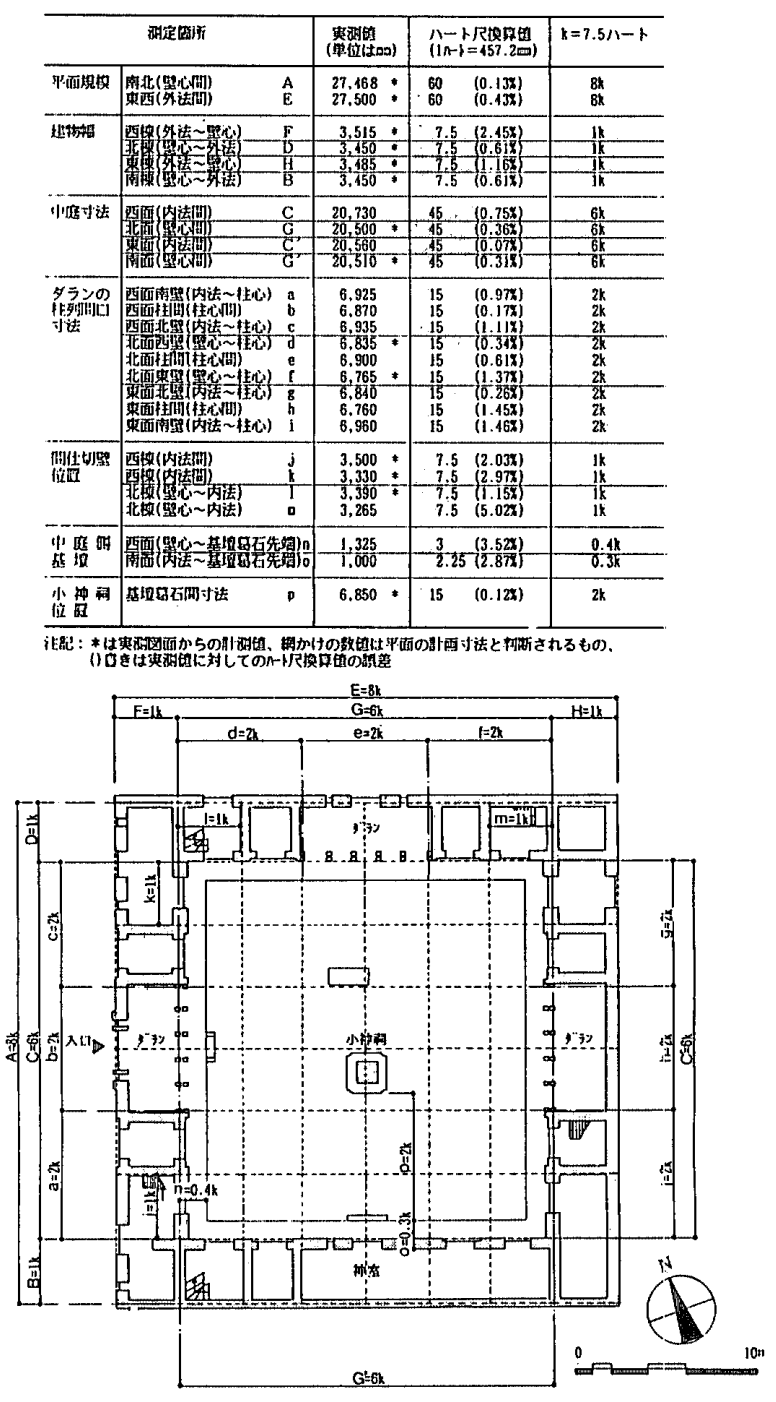

図一6 パタン王宮ムール・チョク平面の実測値とハート尺 
い。前節で仮定した壁厚に基づく基準寸法が，個々の平 面の実測寸法とも対応している。このように，1階平面 の各主要寸法をハート尺に換算して整理したのが図一6 である。

例えば，中庭を囲む建物の幅は $3,475 \mathrm{~mm}$ [4 棟の平 均值 $=(F+D+H+B) / 4]$ で, $7.5 H$ である。中庭寸 法は, 南北 $20,560 \mathrm{~mm}$ (東面 $\mathrm{C}^{\prime}$ ), 東西 $20,510 \mathrm{~mm}$ (南 面 $\mathrm{G}^{\prime}=19,880 \mathrm{~mm}+$ 壁厚 $630 \mathrm{~mm}$ ) で, $45 H \times 45 H$ で ある。中庭中央部にあるダランの柱列間口は，西・北・ 東棟の平均值 $6,843 \mathrm{~mm}[b+e+h) / 3]$ で, $15 H$ であ る。れんが壁と柱列位置の寸法は $7.5 \mathrm{H}$ の倍数となっ ている。この場合の実測寸法に対するハート尺換算値の 誤差は, 順に $1.32 \%, 0.07 \%, 0.31 \%, 0.22 \%$ である。

すなわち，パタン王宮ムール・チョクの基準寸法 $k=$ $10 a$ の值は, 記録に出てくる $7.5 H$ と一致しており, $k=7.5 H$ がムール・チョク平面の基準寸法であるとい える。

パタン王宮ムール・チョクの基準寸法は, 14 世紀末 以来の間笔の長さ $7.5 \mathrm{H}$ と等しい長さである。この間 竿長さ $7.5 \mathrm{H}$ は, 以下のように，ムール・チョクが創 立されたバドガウン王宮における 15 世紀半ばのム一 ル・チョク造営時の基準寸法と考えられる。

バドガウン王宮ムール・チョクの平面外法は, 北棟で 東西 $27,300 \mathrm{~mm}$ である ${ }^{131}$ 。この寸法のハート尺換算值 は $60 \mathrm{H}$ である。この場合の実測寸法に対するハート尺 換算值の誤差は $0.48 \%$ であるから, 東西の平面外法は $60 H$ とみてよい。 $k=7.5 H$ を基準寸法と仮定すると, 壁位置との対応関係から, その平面には $8 k \times 8 k$ の正 方形基準格子が設定できる。すなわち, 間竿の長さ $7.5 \mathrm{H}$ は，バドガウン王宮ムール・チョクの基準寸法でもあ る。

したがって，バドガウン，カトマンズ，パタンの 3 王 国のなかで, 最も遅れて 17 世紀初めに造営されたパ夕 ン王宮ムール・チョクでは, 本来のムール・チョクの形 式を踏襲して，7.5H を一単位とした基準寸法 ${ }^{(4)}$ を採用 したと考えられる。

スンダラ・チョク スンダラ・チョクの基準寸法の 場合, $s=10 b$ の值は図一7 に示すように, $s=6.875 \mathrm{H}$ に換算され，7.5 H とは異なった値が示される。

パタン王宮スンダラ・チョク平面の基準寸法 $10 b$ は, ハート尺換算值で $6.875 H$ である。このチョクにおけ る四周の建物の平面規模は, $60 b \times 60 b$ である。これ を夷測寸法で検証すると, 南側外周壁と北側外周壁の壁 心間寸法が $18,890 \mathrm{~mm}[A=18,260 \mathrm{~mm}+$ 壁厚 $630 \mathrm{~mm}]$, 西側外周壁と東側外周壁の壁心間寸法が $18,960 \mathrm{~mm}[E$ $=18,330 \mathrm{~mm}+$ 壁厚 $630 \mathrm{~mm}]$ で，八ート尺の換算值は $41.25 H \times 41.25 H$ となる。この場合の実測寸法に対す るハート尺換算值の誤差は， $0.16 \% ， 0.53 \%$ である。

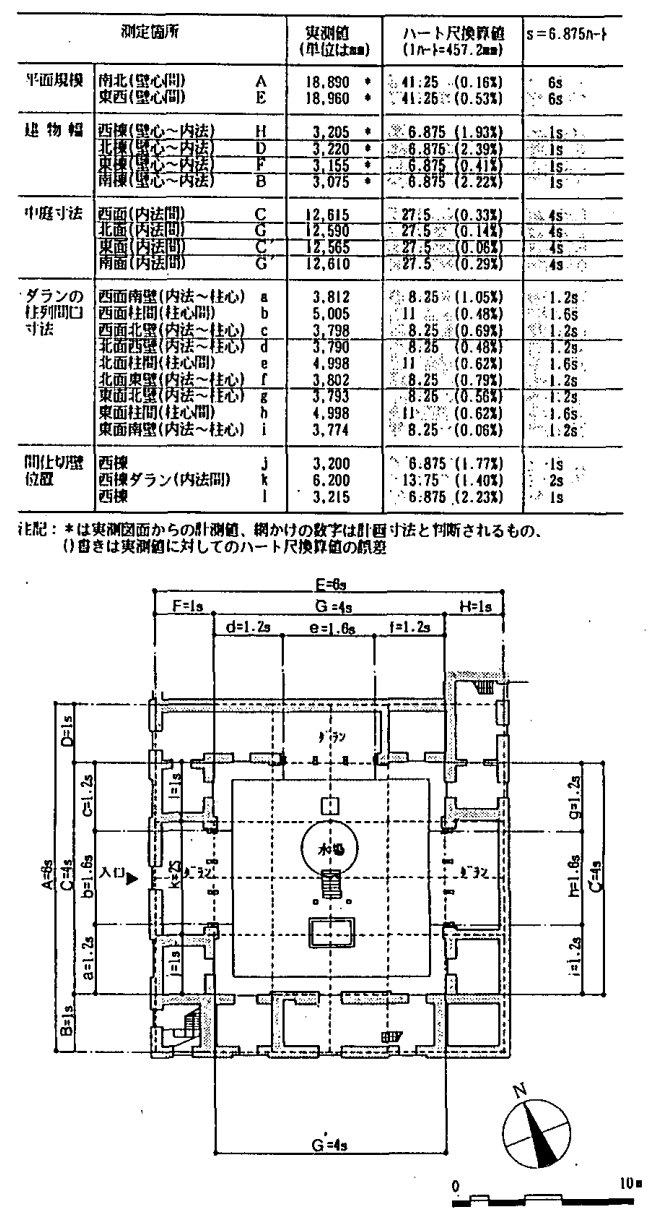

図一7 パタン王宮スンダラ・チョク平面の実測值とハート尺

この正方形の一辺は基準寸法の 6 倍にあたるから，その 6 分の 1, すなわち $6.875 H$ が基準寸法である ${ }^{151}$ 。

また，スンダラ・チョクにおける四周の建物の幅は, 外周壁壁心から内周壁面まで $3,164 \mathrm{~mm}$ [4棟の平均值 $=(F+D+H+B) / 4]$ で，基準寸法の長さ $6.875 H$ と なる。さらに中庭寸法は, 南北 $12,565 \mathrm{~mm}$ [東面 $\mathrm{C}^{\prime}$ ], 東西 $12,610 \mathrm{~mm}$ [南面 $\mathrm{G}^{\prime}$ ] であるから，27.5 H×27.5 $H$ である ${ }^{161}$ 。実測寸法に対するハート尺換算值の誤差 は, $0.06 \%$ と $0.29 \%$ である。

すなわち，スンダラ・チョクの基準寸法 $s=10 b$ の 值は $s=6.875 H$ となり, $7.5 \mathrm{H}$ とは異なった值が示さ れる。

したがって，パタン王婜のムール・チョクとスンダ ラ・チョクの基準寸法は，ハート尺においては，いずれ も端数を伴う值となっている。しかし，ムール・チョク における $7.5 \mathrm{H}$ は, 間笔としての歴史的意味が明らか である。いっぽう, スンダラ・チョクにおける $6.875 \mathrm{H}$ は, 設計上の概念と具体的な工法の融合の結果, 成立し たと推測される。すなわち、スンダラ・チョクの場合は, 建物の平面規模に合わせて基準寸法を小さくしたためと 考えられる。この理由は後の 5 節でさらに考察する。 
4. パタン王宮の配置計画一ムール・チョク

\section{およびスンダラ・チョクを包括する配置計画}

パタン王宮では，まず 17 世紀初めにムール・チョク を創建し，その基準寸法は，前節で述べたように 14 世 紀末以来の間竿長さ $7.5 \mathrm{H}$ を用いている。平面規模は, $7.5 \mathrm{H}$ の整数倍で計画している。そこで, 基準寸法 $k=$ $7.5 H$ を 17 世紀半ばに完成したスンダラ・チョクにも 適用して，ムール・チョクとの配置関係をみると図一8 のようになる。

この図のように,ムール・チョクとスンダラ・チョク の配置は，基準寸法 $7.5 \mathrm{H}$ の正方形基準格子上にあり, これが全体を包括する計画となっていると考えられる。 すなわち，ムール・チョクの南北方向の通り心を延長す ると，スンダラ・チョクの南北中心軸に合う。また，こ の中心軸を基準とする $6 \times 6$ の正方形基準格子は，概标 スンダラ・チョクの基壇部分の平面規模となっている。

その結果, 前節で明らかにしたスンダラ・チョク平面 の $6 s \times 6 s$ の正方形基準格子とは異なる， $6 k \times 6 k$ の 正方形基準格子が設定される。この基準格子の南北の基 準線は，ムール・チョクの(1) (7)の通り心を南側に延長 したものである。そして，(4)通りはスンダラ・チョク平 面の中心軸之ほぼ合う ${ }^{17)}$ 。(2)(6通りは，内周壁内面と一 致する。東西方向の通り心では, 通りが平面の中心軸, (®)通りが内周壁内面と一致する。さらに，一辺 $7.5 \mathrm{H}$ の正方形基準格子を 2 等分する基準線を想定すると，そ の位置に中庭の基壇の葛石先端, 円形の水場の東西中心 軸が一致する (図一9)。すなわち、スンダラ・チョクの 基壇部分の位置は， $7.5 \mathrm{H}$ を基準寸法として計画してい る。したがって，この二つのチョクの配置計画は一貫し たものであったと考えられる。

なお，ムール・チョクの南端の通り心(1)とスンダラ・ チョクの北端の通り心すの間隔は, $698 \mathrm{~mm}$ であり, 双 方のチョクは約 $1.5 \mathrm{H}$ 離れて建つ。この寸法もムール . チョクの外周壁のれんが壁厚 $1.5 \mathrm{H}$ に相当し，基準寸 法の 5 分の 1 であるから，基準格子と対応していると考 えてよい。これは，ムール・チョクとスンダラ・チョク の配置が統一したものであり，等しい長さの基準寸法で 計画しているからである。

\section{5. ムール・チョクと異なる基準格子平面を持つ スンダラ・チョクの計画過程}

パタン王宮スンダラ・チョクの中庭を囲む四周の建物 は，6.875 H の基準格子上につくられているが，中庭基 壇部分までは，全体の配置計画の $7.5 \mathrm{H}$ の基準格子上 で計画されている。この過程を以下で検討する。

パタン王宮の $7.5 \mathrm{H}$ という基準寸法は, バドガウン 王宮ムール・チョクで考定される，間竿長さ $7.5 \mathrm{H}$ を 古式に倣い採用したと考えられる。スンダラ・チョクの

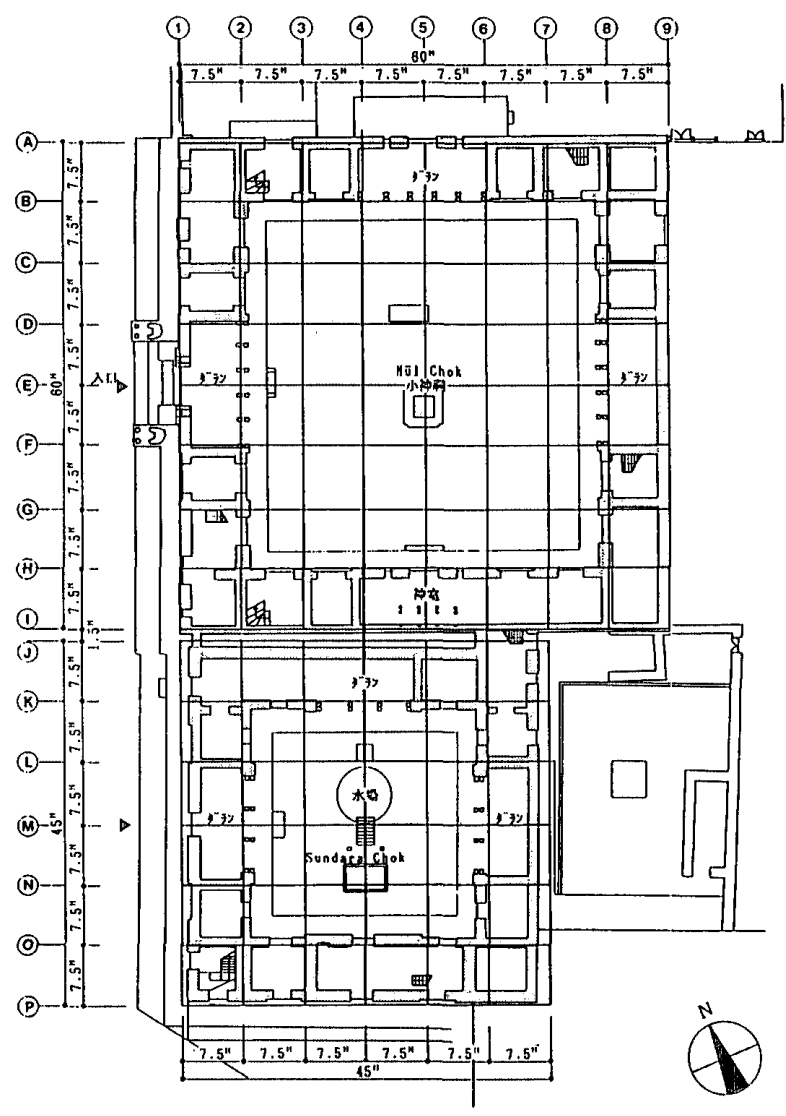

凡例 (1)なとは通り心郡夏

図一8 パタン王宮ムール・チョクおよびスンダラ・チョクの 配置計画
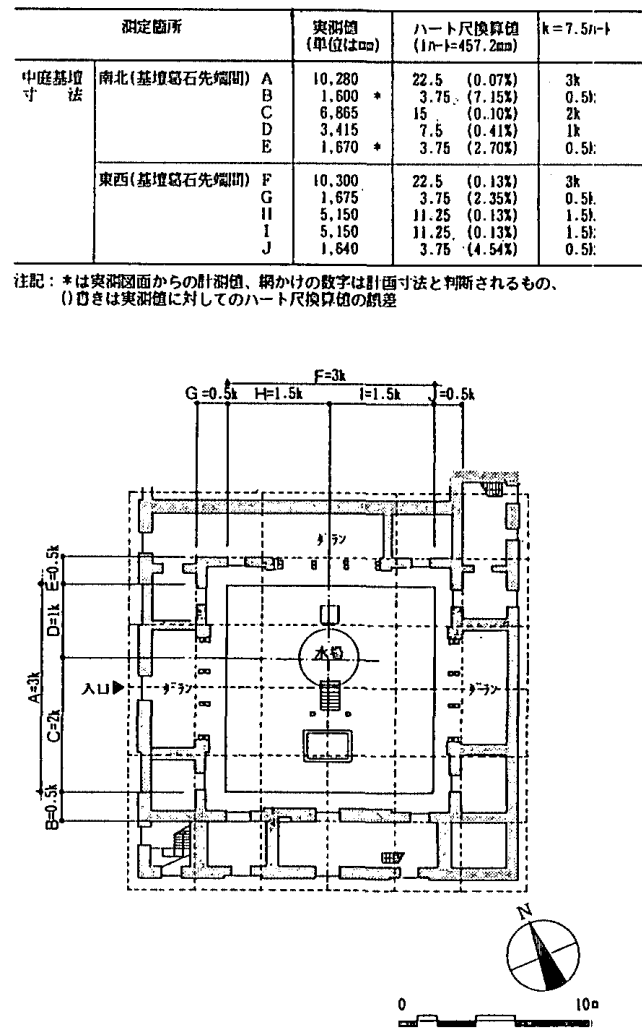

图一9 パタン王宮スンダラ・チョク中庭基壇部分の 実測値とハート尺 
水場を含む中庭に，ムール・チョクの基準寸法がみられ るのは,この時, 基壇部分を整備したためと推測できる。

すなわち，ムール・チョクとスンダラ・チョクは王宮 の中心的な建築であったから，パタン・マッラ王国独立 後，ただちに一貫した建築として王宮の中心的位置に配 置計画したと考えられる。

その後，スンダラ・チョクの建物の造営においては, $7.5 \mathrm{H}$ を採用せず，基準格子は配置上の基準線(4)通り を平面の中心軸とした，やはり $6 \times 6$ としている。ただ， 一単位が一廻り小さくなうている。これは，れんが壁の 壁厚を薄くしているためで'18)，これに基づいた計画とし ているわけである。そして，基準寸法の 6 倍を一辺とす る平面の構成概念は墨守されている。すなわち,このチョ クの平面計画においては，ムール・チョクに $8 \times 8$ の正 方形基準格子 ${ }^{19}$ に対して，6×6 の正方形基準格子の概 念が重要であったといえる。

このように基準単位の長さが建築の用途などにより異 なる設計概念は, 古代インドの建築書に認められ201, ネ パールでも同様に，建築の格や種類などにより異なる基 準格子と基準寸法を用いた可能性が考えられる。

\section{結}

チョク建築の設計方法は，チョク建築が群として一貫 した配置計画の下で行なわれている。すなわち，パタン 王宮においては，ムール・チョクとスンダラ・チョクを 包括する基準格子による配置計画が存在し，その基準寸 法は，ムール・チョク外周壁の壁厚の 5 倍の 7.5 ハート である。この基準寸法 7.5 ハートは,バドガウン王宮ムー ル・チョクでも用いられており，14 世紀末以来のマッ ラ王朝の間竿長さである。全体の配置計画は,こうした 伝統の所産である。

平面計画においては，ムール・チョクは全体の配置計 画の基準格子に合わせ， $8 \times 8$ の正方形基準格子で計画 されており,バドガウン王宮以来の形式を踏襲している。 スンダラ・チョクでも, 中庭基壇部分までは全体の配置 計画の基準格子上に計画している。しかし，中庭を团む 四周の建物は，別の基準格子上につくられており，れん が壁の壁厚をムール・チョクの場合より薄くして，やは り壁厚の 5 倍の 6.875 ハートを基準寸法とし， $6 \times 6$ の 正方形基準格子で計画している。

二つのチョク建築の基準格子の相違は, これらのチョ クが異なる機能の建築であったためと推測される。この ように基準単位の長さが建築の用途などにより異なる設 計概念は，古代インドにもみられ，ネパールにおける王 宮の各チョク建築設計の場合も, 歴史的な背景を意識し て古式か踏襲されていると考えられる。

なお，この研究は日本工業大学を中心とするネパール 王国古王宮調查団による現地調査の成果に基づくもので
ある。調查に際しては，ネパール王国政府，とくに教育 省考古局のご協力を得たことを記し，深く感謝したい。 また，文部省科学研究費補助金を得たことを付記する。

注

1）黒津高行, 渡辺勝彦: チョク建築の構造（ネパールの王 宮における中庭建築の研究 その1), 日本建築学会計画 系論文報告集, 第 408 号, pp. 101 109, 平成 2 年 2 月。

2）拙稿：チョク建築の機能（ネパールの王宮における中庭 建築の研究 その 2), 日本建築学会計画系論文報告集, 第 412 号, pp. $97 \sim 107$, 平成 2 年 6 月。

3）壁厚を $2 a$ と仮定するのは, 補助基準寸法の概念を平面 に適用する時に用いるためである。

4）外壁の一方を「外法」他の一方を「心々」で寸法を決め る手法は，れんが積みの施工手順との関連が考えられる が，その追及は解体調查を待たなければならない。

5) Daniel Wright: History of Nepal translated from the Parbatiya, Cambridge, 1877, reprint, Kathmandu, 1972, p. 184.

A hāth was to be of the length of 24 lengths of the first joint of the thumb.

6) Nepāl Rājakīy Prajñā-Pratișthān : Nepāin Brhat Sabdakosa, Kathmandu, 1983, p.12, p. 967, p. 1414.

7）野口英雄：マーナサーラにみるインドの建築寸法，日本 建築学会近畿支部研究報告集, 昭和 57 年, pp. 601 604。

8) Perceval Landon : Nepal, Vol.1, Kathmandu, 1928, reprint 1976, p.254. 19 世紀末，イギリスはインドの尺度 の基本単位をヤードとした。しかし，一般にはハートな ごの従来慣用の単位が墨守された。このハート尺は, ベ ンガル州，ボンベイ州でも用いられており，1八ートの メートル換算値はネパールと同様に $457.2 \mathrm{~mm}$ とされて いる(須山卓ほか編: 世界各国度量衡便覧, 丸善, 昭和 28 年, pp. 61 - 62, p. 65$)$ 。なお，この論文ではハートの 単位をメートル法で換算し, ミリメートルに統一して表 記する。

9) Prasanna Kumar Acharya : Architecture of Manasaratranslated from Original Sanskrit, London, 1934, 2nd edition, New Delhi, 1980, p. 8.

10）佐伯和彦：ネパール古代・中世史の基礎的論考（仏教芸 術，第 152 号，每日新聞社，昭和 59 年，所収） p. 41 。

11） D. Wright 前揭書注 5) p. 184.

Formerly the Tāngo or bamboo measuring-rod was 101/2 hāths in length, but Rājā Jayasthiti Malla reduced in to $71 / 2$ hăths.

12) Gautamabajra Bajrācārya : Hanūmāndhokā Rājadarbar Kathmandu, 1976, pp. 272 278.

13) Niels Gutschow: Courtyard Buildings in Nepal-The Palaces, Temples and Monasteries of the Newars, Vijayanagara-City and Empire, New Currents of Research, 1985, p. 365, Fig. 2.

14）パタン王宮ムール・チョク南棟中央の屋根上に建つアガ ン寺は, 異なる基準寸法で計画している。ムール・チョ クに塔を併設する形式は，本来のムール・チョクにない ものであるから，これは例外として扱ってよい。

15）この基準寸法はハート尺の整数値よなっていないが,こ れは, 平面配置全体の割り付け寸法と係わっているため 
と推测される。基準寸法が端数を伴う点は, ムール・チョ クと共通する。

16) Eduard F. Sekler (Urban Design at Patan Darbär Square-A Preliminary Inquiry, Heritage of the Kathmandu Valley, Nepalica, Band 4, Bonn, 1987, p.58) は, バ タン王宮でのハート尺換算値を 1 ハート $=458 \mathrm{~mm}$ とし て、スンダラ・チョクの立面寸法の比例関係を検討して いるが, 平面の設計概念については論じていない。

17）スンダラ・チョク平面の南北軸は, ムール・チョク平面 の南北軸に対して 3 度ほど東に振れているため, 実際に はその分だけ双方の軸線にずれが生じている。

18）ムール・チョクの外周壁の壁厚 $1.5 \mathrm{H}$ は，ほぼれんが 3 枚厚分に相当し，スンダラ・チョクの外周壁の壁厚 1. $375 \mathrm{H}$ はれんが 2 枚半厚分であると考えられる。ただ， 二つのチョクの各れんがの大きさには相当のばらつきが
あり、この詳細な検討は、解体調査を待たなければなら ない。

19）インドにおいて正方形平面の設計概念には, 神格化され た宮殿の理想型である，ヴァーストゥプルシャマンダラ Vāstupurṣa-manḍala がある。中でも 64 の正方帅からな る $8 \times 8$ の正方形基準格子の平面形は，最も主要なものて 寺院などに適用することが指摘されている (Stella Kramrisch : The Hindu Temple, Vol.1, Delhi, 1946, reprint 1986, p.46.)。この設計概念は，ネパールの王宮建 築においても十分に関係している可能性が考えられる。

20） P. K. Acharya 前揭書注 9), p. 8，およびP.K. Acharya : A Dictionary of Hindu Architecture, London, 1934, 2nd edition, New Delhi, 1981, p. 5, p. 742.

(1991 年 4 月 6 日原稿受理, 1991 年 6 月 14 日振用决定) 